\title{
PSIKONEUROIMUNOLOGY APPROACH TO IMPROVE RECOVERY MOTIVATION, DECREASE CORTISOL AND BLOOD GLUCOSE OF DM TYPE 2 PATIENTS WITH DHIKR THERAPY
}

\author{
Rifka Pahlevi*, Suhartono Taat Putra**, Sriyono*** \\ *Program Studi S1 Keperawatan Stikes Hang Tuah Surabaya \\ **Faculty of Medicine Universitas Airlangga \\ ***Faculty of Nursing Universitas Airlangga \\ Email: rifkapahlevi@gmail.com
}

\begin{abstract}
Introduction: Blood glucose levels are controlled when the management of diabetes success. Positive perception of the strength of the spiritual aspect will improve the motivation of patients with type 2 diabetes to control it. The purpose of this study was to determine the effect of dhikr based on psychoneuroimmunology (PNI) on blood glucose levels of patients with type 2 diabetes. Methods: This study used quasi-experiment with pre-test and post-test control group design. Samples were taken from the population of patients with type 2 diabetes who were hospitalized in the Internal Medicine Rumkital Dr. Ramelan Surabaya with purposive sampling techniques. Data taken include the general characteristics of respondents, cures motivation, cortisol levels and fasting blood glucose levels. Collecting data using questionnaires and laboratory test, then analyzed using paired t-test and independent t-test, with $\alpha$ value $<0.05$. Results: Statistical test showed that the motivation to recover increased $(\mathrm{p}=0.001)$, cortisol levels fall $(\mathrm{p}=0.058)$ and a drop in blood glucose levels $(\mathrm{p}=0.028)$ after administration of dhikr therapy in patients with diabetes mellitus type 2 . There was a significant difference in increased of recovery motivation between patient conduct zikr therapy and patient cared $(\mathrm{p}=0,000)$. Conclusion: Dhikr therapy increases the motivation of patients with type 2 diabetes by strengthening awareness and spirituality belief in Allah make positive stress perception. Positive stress perception will affect the stress response and improved regulation of blood glucose through the HPA axis to suppress the secretion of CRH, ACTH, and cortisol.
\end{abstract}

Keywords: dhikr, diabetes mellitus type 2, recovery motivation, cortisol, blood glucose.

\section{INTRODUCTION}

A preliminary study that has been given to 5 patients with type $2 \mathrm{DM}$ being treated in disease room in Navy Hospital of Dr. Ramelan in Surabaya reveals that two patients of them are found to have been doing dhikr every day during treatment period resulting in blood glucose level decreasing from $>300 \mathrm{mg} / \mathrm{dl}$ when initially admitted to the hospital to $<200$ $\mathrm{mg} / \mathrm{dl}$ in average. Three other remaining patients have never been doing dhikr during the treatment period with blood glucose level of $>200 \mathrm{mg} / \mathrm{dl}$ in average. DM patients are aware of DM management principles, yet many of them still have uncontrolled blood glucose level. Several factors found to affect blood glucose level directly include diet, physical activities, and antihyperglycemic drugs. Meanwhile, factors indirectly affecting include cognition, perception, spirituality and motivation (Ariani 2011). Currently, blood glucose level reduction in patients with type 2 DM doing a spiritual activity (dhikr) is yet to explain.

According to data provided by WHO (2010), Indonesia is the fourth country with most people with DM in the world. Research made by DiabCare in Indonesia reveals that $47.2 \%$ patients with type $2 \mathrm{DM}$ in Indonesia have poor control to blood glucose level with fasting blood glucose level $>130 \mathrm{mg} / \mathrm{dl}$ (Soewondo, et al. 2010). Navy hospital of Dr. Ramelan Surabaya has ranked type 2 DM on the second position from top 10 diseases treated with inpatient treatment, which is 951 cases in 2015 (2015 recapitulated data from Navy hospital of Dr. Ramelan Surabaya). Chronic diabetes mellitus and potentially leading to serious complication often result in both financial and psychological problems as well as degrading life quality (Coffey et al. 2002). Patients with DM frequently suffer from several psychological problems including boredom, desperation, frustration and depression (Schumacher \& Jacksonville 2005).

Change in lifestyle is a necessity for patients with type $2 \mathrm{DM}$ to maintain their life quality. Many types of research have been conducted about management of patients with type 2 DM with various approaches, including, among others, cognitive approach to lecturing/education, effective approach by teaching compliance with diet control and physical activities, psychomotor approach with 
diabetic exercises (Schumacher \& Jacksonville 2005; Sousa \& Jaclene 2005), unfortunately, those interventions, however, won't be lasting since patients will have boredom, even pessimism (Yuana 2013). Human is a holistic creature that consists of biological, psychological, sociocultural and spiritual dimensions that have interrelationships among those dimensions (Potter \& Perry 2009). Imbalance occurring in one dimension will be compensated with the enhancement in another dimension. Psychospiritual aspect plays an equally important role compared to other aspects of maintaining individual health. SelfDetermination Theory mentions that individuals intrinsically motivated, which can make a choice of their needs will be able to adapt and treat themselves directly and maintain their health (for example, blood glucose level control and complication prevention) (Adam 2012);(Ariani 2011). One aspect found to be able to improve individual perception to their ability is spirituality aspect (Baldacchino 2008). Spirituality significantly helps patients in adapting to changes caused by various chronic diseases. Spiritual healing technique held with good regularity and continuity may helpfully support conventional therapy. Spiritual healing in Islam refers to the spiritual belief that affects psychological, physical and spiritual aspects (Ibrahim et al. 2011).

Dhikr is one type of spiritual therapy that is easy to do (spoken, recited silently within the mind and through deeds) and affects cognition by improving perception, positive motivation and effective coping (Sholeh 2009). Psychologically, dhikr provides comfortable feeling and spiritually result in closer feeling with Allah (Khan 2009). Positive perception will then induce hypothalamus to secrete hormones that modulate immunity system. The modulation, in turn, results in lowered HPA axis activity leading to lowered cortisol level. Lowered cortisol level affect metabolism that decreases insulin resistance (improving blood glucose uptake into cell and tissue) and prevents glucogenesis. Therefore blood glucose level is controlled (Brown 2012; Putra 2011).

\section{METHOD}

This study used quasi-experiment (pre and post test control group design). This research was conducted in Dr. Ramelan Navy Hospital Surabaya after getting ethical clearance from the ethical commission of Dr. Ramelan Navy Hospital. Population were patients with type 2 diabetes mellitus who hospitalized in Rumkital Dr. Ramelan Surabaya in June 2016 (37 patients), samples were patients according to criteria of inclusion and exclusion using purposive sampling technique, there were 19 patients, that divided into two groups, 10 patients in intervention group, and 9 in control group. Independent variable in this study was dhikr therapy. The dependent variable in this study was the recovery motivation, blood glucose and cortisol level of type 2 DM patients. The research instruments include: dhikr therapy was given based on the guidebook, recovery motivation was measured using a questionnaire that combines from Stroke Rehabilitation Motivation Scale (SRMS) and The IronsonWoods Spirituality Index. There were 30 questions in the questionnaire, fasting blood glucose and cortisol level was measured using laboratory test. The data has been analyzed using paired t-test, Wilcoxon test, and independent t-test.

\section{RESULT}

Table 1. Analyze result deferent test (pre-post) recovery motivation, cortisol and blood glucose level in intervention group

\begin{tabular}{llll}
\hline & Mean & SD & P-value \\
\hline Recovery motivation pre-intervention & 88,3 & 5,69 & T-test 0,001 \\
Recovery motivation post-intervention & 98,6 & 5,04 & \\
Cortisol level pre-intervention & 26,91 & 8,67 & T-test 0,058 \\
Cortisol level post-intervention & 19,24 & 8,25 & \\
Blood glucose level pre-intervention & 257,6 & 69,26 & Wilcoxon 0,028 \\
Blood glucose level post-intervention & 201,3 & 47,01 & \\
\hline
\end{tabular}


Table 2. Analyze result deferent test (pre-post) recovery motivation, cortisol and blood glucose level in control group

\begin{tabular}{llll}
\hline & Mean & SD & P-value \\
\hline Recovery motivation pre-intervention & 88,3 & 5,69 & T-test 0,001 \\
Recovery motivation post-intervention & 98,6 & 5,04 & \\
Cortisol level pre-intervention & 24,87 & 6,64 & Wilcoxon 0,260 \\
Cortisol level post-intervention & 25,15 & 8,11 & \\
Blood glucose level pre-intervention & 257,6 & 69,26 & Wilcoxon 0,028 \\
Blood glucose level post-intervention & 201,3 & 47,01 & \\
\hline
\end{tabular}

Table 3. Analyze result different (post-post) delta recovery motivation, delta cortisol level and delta blood glucose level in intervention group and control group

\begin{tabular}{|c|c|c|c|}
\hline & Mean & SD & P-value \\
\hline $\begin{array}{l}\text { Recovery motivation post-intervention in intervention } \\
\text { group }\end{array}$ & 98,6 & 5,04 & T-test 0,000 \\
\hline Recovery motivation post-intervention in control group & 86,7 & 4,06 & \\
\hline Cortisol level post-intervention in intervention group & $-7,66$ & 11,16 & T-test 0,115 \\
\hline Cortisol level post-intervention in control group & 0,28 & 9,49 & \\
\hline $\begin{array}{l}\text { Blood glucose level post-intervention in intervention } \\
\text { group }\end{array}$ & $-56,3$ & 69,38 & T-test 0,592 \\
\hline Blood glucose level post-intervention in control group & $-39,0$ & 68,30 & \\
\hline
\end{tabular}

\section{DISCUSSION}

\section{Difference in motivation to recover in patients with type 2 DM between treatment and control groups}

Table 3 reveals that difference in motivation to recover in patients with type 2 DM between treatment and control groups after receiving intervention for the period of five days is significantly different. The finding is also clarified by figure 1 showing positive average delta value of patients doing dhikr, while patients in control group showing negative average delta value.

In the concept of PNI, stressor received by an individual will be responded by two responses, including stress perception and stress response. Stress perception comes in the form of the learning process to produce a positive response. When the response is positive, the resulting response will be adaptive. This is in accordance with research by Hardhiyani (2013) stating Islamic spiritual guidance may improve motivation of patient with DM to recover. Prayitno (2015) suggests that prayer and dhikr may be used as a method to lower depression of those with chronic diseases, where lowered motivation is a preliminary sign of depression. Motivation is a process that simply occurs, rather underlined by certain requirement (motive) that drive the motivation. Motivation occurring within oneself is highly affected by his/her perception. Perception is transaction process of judging an object based on individual's previous experience, attitude, expectation, values, and spirituality (Hardhiyani 2013).

Dhikr in this research serving as stressor consists of three types, including jahr, sir and fi'ly. Dhikr of jahr that is spoken will be captured by the organ of hearing passing to the brain through temporal lobe (God spot), which is a tiny nerve able to respond to religious and divine aspects (center of spirituality) and then continued to prefrontal cortex. Dhikr's of jahr and sirr (recited silently within the mind) are then fused in prefrontal cortex in the form of the deliberative learning process through processes of selection, organization and interpretation to a stressor (recitals and meanings of dhikr verses) received that result in positive perception. In order to optimize the learning process in patients with type $2 \mathrm{DM}$, an emphasis should be given to meanings of each recital of dhikr's, so with the help of cognitive understanding, will help awareness rising from learning wisdom to controlling temper and improving motivation of patients with type 2 
DM. The forming of positive perception is then strengthened by dhikr of fi'ly that integrates between mind, feeling and attitude into one single entity to obtain God blessings. Therefore, a perception developed with the improvement of spirituality aspect (dhikr) will affect the psychological reaction, which is motivation to recover and visible behaviors.

\section{Difference in blood glucose level in patients with type 2 DM between treatment and control groups}

Table 3 reveals that no significant difference is observed in cortisol level between treatment and control groups. The finding is clarified by figure 2 showing patients doing dhikr have changing negative cortisol level (lowered) in comparison to control groups, despite slight difference.

This is according to research (Satiti 2013) that the dhikr can calm down, reduce stress and depression, as well decrease cortisol levels. (Sholeh 2009) Suggest that tahajud praying therapy by approaching psychoneuroimmunology shows that prayer is humility can increase endurance, reduce the risk of heart disease and increase life expectancy for this therapy can lower cortisol levels. Antoni et al. (2006) mention the emotional and spiritual response were controlled by providing materials and training of remembrance and focus praying in some nurses can decrease cortisol levels than the average nurse $181.14 \mathrm{ng} / \mathrm{ml}$ to $88.43 \mathrm{ng} / \mathrm{ml}$.

Dhikr which done with awareness and sense of sincerity including the integration and relationship of body and soul can improve healthy by setting breathing gently, surrender, voiced jahr and sirr, concentration to maintain the balance of the unification of the self, both physically and spiritually to an object that is God (Wilcox 2003). The psychological dynamics through spiritual activities (meditation, remembrance, prayer, prayer) will make a person feel a closeness with God and experience the relaxed state (relaxation), quiet and peaceful (Istiqomah 2011). When remembrance (relaxation) occurs activation response relaxation areas such as the amygdala and hippocampus. Another effect is influenced by the remembrance race molecular signal. Molecules such as nitric oxide, endocannabinoids, endorphin or enkephalin role in the placebo response that causes a feeling of comfort and relaxation as well as have the capacity antagonist to stress. Effects of the relaxation response and the molecular signals that cause repose of the respondents who followed the standard intervention room with reme of the respondents group who followed the standard intervention room with dhikr.

Besides other lines is due dhikr causes relaxation therapy is expected to activate brain structures such as the frontal lobe and limbic areas, indicating the important role of emotions and beliefs, will also improve the immune system and decrease cortisol levels.

In the concept of psychoneuroimmunology, dhikr as a stressor affects the stress perception and stress response that occurs in the body. Stress response occurs through setting nervous and endocrine systems in producing neurotransmitters and hormones that modulate the immune system, one through the HPA axis. Emotions which are controlled in amygdala can affect the hypothalamus in reducing the secretion of $\mathrm{CRH}$, a decline of $\mathrm{CRH}$ will be responded by the adrenal to reduce secretion of ACTH, it can decrease cortisol secretion in the adrenal cortex, so that the stabilization of emotional and spiritual states can be observed from the adrenal hormone fluctuation.

\section{Difference in blood glucose level in patients with type 2 DM between treatment and control groups}

Table 3 reveals that no significant difference is observed in blood glucose level between treatment and control groups. The finding is clarified by figure 3 showing patients doing dhikr have changing negative blood glucose level (lowered) in comparison to control groups, despite slight difference.

One channel playing a role in regulating blood glucose level is HPA axis through modulated cortisol (Sherwood 2011). Modulated cortisol through dhikr therapy as discussed earlier will affect metabolism process in the body, through the suppression of catalyst enzyme production in the process of glycogenesis in liver (glucose 6-phosphatase enzyme), thus leading to lowered protein decomposition rate to become glucose. Another metabolism effect of the lowered cortisol level in the long term is to increase cellular sensitivity to insulin which is the main 
issue patients with type 2 DM (Black \& Hawks 2009). (Yanti 2012) Has proved that dhikr therapy for the period of five (5) days (conducted twice a day) has higher effectiveness in reducing blood glucose level in patients with type $2 \mathrm{DM}$ in comparison to Benson relaxation. Research by Sofia (2012) shows that combination of Fluoxetine and Self Surrendering Practices can improve blood glucose level control, inflammation degree and life quality of diabetic patients suffering from depression.

Meanwhile, blood glucose of control group measured after intervention shows reduction as well, yet not significantly different. Reduction observed in blood glucose in control group mostly due to effect of diabetes mellitus medication in the disease room, which is insulin-giving therapy not followed with improvement in perception (proven with lowered motivation to recover), thus lowering blood glucose level not significantly different as with treatment group. This clarifies the importance of providing treatment to patients with type 2 DM starting with improvement in perception about his/her illness condition, therefore leading to higher effectiveness in other therapies involved, in this case including medical therapy (curing) in order to maintain controlled blood glucose.

Diabetes is considered multifactor disease since many factors have influence and to control them, good management is required from various aspects, including, knowledge, understanding, attitude and behavior. Fluctuation in blood glucose of patients with type $2 \mathrm{DM}$ is affected by several factors, including diet, physical activities, physical and emotional stress as well as antidiabetic drugs or insulin (Ariani 2011). Taken those factors into account, one can say that to maintain controlled blood glucose, a synergistic relationship is required to exist between the state of mind affecting body's physiological process and the establishment of positive behavior. Observing those factors, then dhikr of jahr, sirr and fi'ly have an influence on emotional stress controlling factor as an initial response in perception process. It is then visible in patient motivation to recover. In the next stage, it will impact physiological response in the body through neurohormonal regulation in this case HPA axis (cortisol level), while to obtain positive behavior response in the form of compliance in diabetic management (diet, physical exercise) requires longer time with higher intensity (Ariani 2011); (Fishier et al. 2010) In research by Aini et al. (2010), motivation and education given through home visit for the period of one (1) month (once in a week) may improve patient behavior in DM management. Cortisol regulation therefore is one of many factors that affects blood glucose level in patients with type $2 \mathrm{DM}$.

\section{CONCLUSION}

Psychoneuroimmunology approach using dhikr therapy improve blood glucose regulation through increased recovery motivation, decreased cortisol and blood glucose level.

Improve stress perception to repair stress response is needed to increase health quality level. Nurses can improve patient's perception through giving an understanding about the purpose of life (worship God) and instill positive thinking on everything, especially in patients with chronic diseases.

\section{REFERENCES}

Adam, L.O.B., 2012. Peran Motivasi Spiritual Agamis terhadap Organizational Citizenship Behavior ( OCB ) dan Kinerja Dosen ( Studi pada Dosen Universitas Haluoleo Kendari ). , 10.

Ariani, Y., 2011. HUBUNGAN ANTARA MOTIVASI DENGAN EFIKASI DIRI PASIEN DM TIPE 2 DALAM KONTEKS ASUHAN KEPERAWATAN DI RSUP. H. ADAM MALIK MEDAN.

Baldacchino, D.R., 2008. Teaching on the spiritual dimension in care: The perceived impact on undergraduate nursing students. , Volume 28(Issue 4), pp.501-512.

Black, J.M. \& Hawks, J.H., 2009. Medicalsurgical Nursing: Clinical Management for Positive Outcomes J. M. Black \& J. H. Hawks, eds., Saunders/Elsevier.

Brown, T., 2012. Rapid Review Physiology 2nd ed., Philadelphia: Mosbay inc an affiliate of Elsevier inc.

Coffey, J.T. et al., 2002. Valuing HealthRelated Quality of Life in. , 25(12), pp.38-43.

Fishier, L., Glasgow, R.E. \& Strycker, L.A., 2010. Distress and Clinical Depression 
With Glycemic Control Among Patients With Type 2 Diabetes. , 33(5), pp.10341036.

Ibrahim, N., Desa, A. \& TOng, N.K.C., 2011. Illness Perception and Depression in Patients with End-Stage Renal Disease on Chronic Hemodialysis.

Istiqomah, I., 2011. Penurunan Adiksi pada Penyalahgunaan Narkoba yang Melakukan Ddhikr di Ponpes Inabah XIX Surabaya Tahun 2011.

Putra, S.T., 2011. Psikoneuroimunologi Kedokteran 2nd ed., Surabaya: Airlangga University Press.

Satiti, N., 2013. Penurunan Kadar Kortisol dan Perubahan Stress Persepsi pada Pasien Kusta yang mengalami distress dengan menggunakan modifikasi Cognitive Behavioural Stress Management (CBSM)-Dhikr Asmaul Husna di Rumah Sakit Kusta Sumber Glagah Mojokerto,

Schumacher, E. \& Jacksonville, S., 2005. Diabetes Self Management Education:
The key to living well diabetes. Available at: http://www.dcmsonline.org/jaxmedicine/2005journals/diabetes/diab05jpt-education.pdf.

Sherwood, L., 2011. Fisiologi Manusia: Dari Sel ke Sistem 6th ed., Jakarta: EGC.

Sholeh, M., 2009. Terapi Shalat Tahajjud: Solusi Praktis Menyembuhkan Berbagai Penyakit, Jakarta: Hikmah Jakarta.

Sousa, V.D. \& Jaclene, Z., 2005. Toward a Theory of Diabetes Self-Care Management. Journal of Theory Construction and Testing.

Wilcox, L., 2003. Ilmu Jiwa Berjumpa Tasawuf: Sebuah Upaya Spiritualitasi Psikologi, Jakarta: SIS.

Yanti, N., 2012. Perbandingan efektivitas terapi ddhikr dengan relaksasi benson terhadap kadar glukosa darah pasien diabetes mellitus di Sumatera Barat.

Yuana, 2013. Gambaran Motivasi Pasien DM dalam Menjalankan Program Manajemen Diabetes, Surabaya: Skripsi, Stikes Hang Tuah. 